\title{
The Post-Colonial Administrative System in Tanzania 1961 to 2019
}

\author{
Osmund Kapinga $^{1 *}$, Victoria A Gores ${ }^{2}$ \\ ${ }^{1}$ St. Augustine University of Tanzania \\ ${ }^{2}$ Mwenge Catholic University Tanzania
}

Article History

Received: 25.08.2020

Accepted: 22.09 .2020

Published: 10.10 .2020

Journal homepage:

https://www.easpublisher.com/easjhcs

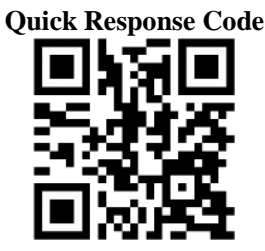

Abstract: This paper deals with different areas which are the fundamentals of Administrative System in Tanzania. It focuses on dissecting the Tanzania post colonial state in discharging its duties to the masses, reflect on colonial administrative system as an oppressive, exploitative and humiliating institution and post colonial administrative system as developmental agency, identification and analysis of post colonial administrative structure and functions. Lastly, to assess the functioning of the administrative organs by linking them to the basic needs of the masses. Methodologically the paper has been designed from historical exploratory design. The approach engaged in this paper is that of qualitative nature utilizing both primary and secondary historical sources to gather information through in depth interviews, oral histories, observation and intensive archival documentary review. Research instruments such as interview guides and checklists were designed to facilitate smooth collection of the required data. Most of the secondary data were generated from libraries at SAUT, MWECAU, UDSM, National Library DSM, Mwanza Regional Library and Kilimanjaro Regional Library. The findings revealed that there were high hopes among the masses that throughout the struggle for independence rallied behind TANU which was the vanguard of the struggle for uhuru. It is now 59 years of uhuru yet the basic problems disease, poverty and ignorance which united the masses against colonial administration are still in place. The situation is more precarious in health, wellbeing, economy and human security.

Keywords: Post Colonial Tanzania, Uhuru, Patriotism, Administration and Nation Building.

Copyright ( 12020 The Author(s): This is an open-access article distributed under the terms of the Creative Commons Attribution license which permits unrestricted use, distribution, and reproduction in any medium for Non Commercial use (Non Commercial, or CC-BY-NC) provided the original author and source are credited.

\section{INTRODUCTION}

Africa also faces a number of other challenges which must be overcome in order to achieve poverty eradication and socio-economic development. The magnitude and complexity of the challenges require the adoption of sound governance and public administration institutions and practices [1]. Designing, inventing and strengthening institutions of governance and public administration at the national level, including: redefining the mission of the postcolonial state and grounding governance and public administration in local conditions; developing, strengthening and popularizing national constitutions and constitutionalism as agreed foundations for good governance and public administration within the rule of law; participatory design of comprehensive nation-wide programmes for strengthening governance; strengthening public sector institutions (legislative institutions, the judiciary, the civil service); adopting institutions in the public service that ensure partnerships, adaptability, citizen-orientation and information-sharing; strengthening institutions of

\footnotetext{
${ }^{1}$ UN Committee of Experts on Public Administration, 2004, Developing institutions of governance and public administration in Africa Report of the Secretariat
}

participatory democracy and local governance; and harmonizing traditional and modern institutions of public administration.

Tanganyika achieved her independence in December 1961 through constitutional struggle. There were high hopes among the masses that throughout the struggle for independence rallied behind TANU which was the vanguard of the struggle for uhuru. It is now 58 years of uhuru yet the basic problems disease, poverty and ignorance which united the masses against colonial administration are still persistent [2]. The situation is more precarious in health, wellbeing, economy and human security.

\section{Conceptualization of post-colonial predicaments}

There are many explanations advanced by different groups of people ranging from pessimists (mabeberu) and the optimists (the praise team) contenting around the achievements of the post-colonial state in Tanzania in particular and Africa in general. Among the theories advanced to explain this predicament include the functional theory which anchors on the functioning of the government

${ }^{2}$ Nyerere named the national enemies 1961 
instruments without grasping the historical movement of the post-colonial state in general and the postcolonial government in particular. Other theories include the bourgeois theories [3] which are advanced by the imperialists. The Marxist theories [4] which believe that for the state and governments to be responsive to the masses in order to be accountable it has to be created by the exploited class (proletariat) through revolution. The developmentalist theories [5] which believe that the task of the post-colonial states and governments is to serve the people by bringing them development. Khan (2010) notes that the strength of the political settlement in the first period after independence exhibited the characteristics of a developmental state, an outcome forestalled by the focus on strengthening the state and forging a national identity, rather than on promoting productive economic sectors[6].

Post-independence state power on the African continent. The discussion is critical of Mamdani's argument that post-independence authoritarianism in Africa can be understood as an institutional legacy of late colonialism [7]. The administrative system adopted by the independent government in Tanganyika was that of Westminster model inherited from the British colonial masters. The nature, scope, structure and functions of administrative system in any country is a product of sociohistorical context [8]. While evolution of administrative system in capitalist countries has been consistent with their socio historical conditions the formation of administrative structures in developing world took place in isolation with from their indigenous contextual realities. The origin of these relatively contextless of public administrative system can be traced back from their colonial experience [9]. Despite the end of colonial direct rule in Africa the bureaucratic legacy of the colonial continued not only in

3 The argument of these theories contends that governments are responsible for arbitration between the rulers and the ruled.

${ }^{4}$ The argument anchors on state as a product of class antagonism between the exploiter and the exploited

${ }^{5}$ They argue that state is an agency of change in newly independent states

6 Stein Sundstøl Eriksen, Tanzania: A Political Economy Analysis, Norwegian Institute of International Affairs 2018

7 Mamdani, M. 1996. Citizen and Subject: Contemporary Africa and the Legacy of Late Colonialism. Princeton: Princeton University Press.

${ }^{8}$ M Shamsul Haque, Context less nature of public administration in third world countries, International Review of Administrative Sciences, vol 62 (1996) pp 315-329

9 Ankomah 1981, Harris 1990, Hopkins 1991 Ayugi 1989 bureaucratic structure, function, classification, functions, recruitment, socialization, norms and attitudes, but also in terms of adverse administrative features such as paternalism, elitism, despotism, secrecy, centralism, formalism, alofness and rigidity.

The formation of this legacy began with preindependence preparation for self-government based on colonial education and administration was perpetuated further during the postcolonial period through various means including higher education, foreign training, international experts, technical assistance, and administrative reforms. Most third world countries introduced changes based on foreign knowledge and experience rather than the indigenous contexts thus reinforced colonial legacy. Development administration as a concept popped up in the field of administration brand to depict this new experience imitating the western administrative model and served to maintain the dominance of western ideological superiority over developing world. This model developed rested in the social contract based on the Tanzania people who unified around anti-colonial struggles which reflected their aspiration and hopes regarding increased employment, higher wages and the satisfaction of basic needs which were to trickle down to everyone.

Africa's underlying political realities were, first, its people's predominantly local concerns, and to judge their representatives and the state by their services to local advancement. Secondly, independent regimes faced Africa's ancient obstacles to statecreation: huge underpopulated areas, poor communications, limited literacy, resistance to the extraction of surplus by poor people jealous of their freedom, and codes of honour that encouraged the ostentatious show of power. Thirdly, arbitrary international boundaries, regional and social rivalries between rich and poor, growing populations pressing on resources, volatile capital cities, the overweening power of modern weapons, and a view of the state by its agents as primarily a source of income and advancement. Finally, these problems were compounded by the haste, sometimes the violence, and, paradoxically, the idealism of decolonisation: opportunistic coalitions, regional rivalries mobilized for political competition, constitutions tailored to shortterm ends, anxiety to imitate the most modern nationstates of the time, expectations inflated by easy victories, and locally minded people exercising universal suffrage. To create stable democracies in these circumstances was a task as difficult as any political generation had faced.

Faced with these pressures, most leaders of newly independent states relied first on bureaucracies inherited from colonial rule, generally giving their Africanisation highest priority. Inflated in size, hugely expensive, and as authoritarian as the officials of 
Pharaonic Egypt, these bureaucracies nevertheless provided frameworks without which many new states would have disintegrated, a point illustrated by the stability of former colonies of white settlement where nationalist leaders had inherited the administrations and police forces created to repress them. Yet these were seldom the rational bureaucracies of Weberian theory. Rather, as in nineteenth-century Egypt or Asante, they were to varying degrees patrimonial, in that office was conferred in return for personal loyalty and service to the ruler, in situations where social mobility precluded the organic solidarity of a hereditary ruling class. Such regimes were held together by personal relationships among a small elite, Cameroun's being reckoned in the later 1970s at fewer than a thousand people. Unlike the Sokoto Caliphate, these were governments of men and not of laws. 'System? What system? I am the system', President Bourguiba of Tunisia declared, while President Mobutu's public statements had the full force of law. Each elite member headed a personal clientage, usually on tribal or regional lines, which imposed burdensome obligations but linked him to a locality and supported his claim to be its spokesman and protector, so long as his performance satisfied constituents. In their 'hegemonic project' to dominate society, ruling elites generally drew on three additional institutions. One was a single political party, either inherited from a unified nationalist movement (as in Tanzania), consolidated at independence when opposition leaders hastened to join the victors (as in Kenya), or created as an artificial support group for some usurper (as in Mobutu's Congo). Some single parties were merely mechanisms to prevent real politics while providing harmless arenas for ambition, popularizing state propaganda, organizing political ceremony, channelling patronage, and enforcing social control, especially in otherwise ungoverned towns. Other parties grew this way with time and power, notably the CPP in Ghana and FLN in Algeria. A few were serious attempts to institutionalize as much democracy as leaders believed possible in fissiparous societies. Nyerere in Tanzania articulated this view, which often seemed tattered to those born after independence.

The second supportive institution was the army, but it was a two-edged weapon. African rulers had long struggled to control the disproportionate power of those with guns. Emirates of the Sokoto Caliphate, for example, had suffered several coups d'état. Colonial rule had concealed the problem, so that at independence only Houphouet-Boigny seems to have foreseen the political significance of armies generally recruited from backward regions. By 1984, however, sub-Saharan Africa had experienced fifty-six successful and sixty-five unsuccessful coups d'état, half the continent's governments were of ...

A third and more reliable buttress for regimes was the international order. Until the Cold War ended in the late 1980s, foreign aid gave African rulers extensive patronage at very little cost in dependence. The United Nations founded 1944 and the Organisation of African Unity (OAU), founded in 1963, acted as 'Heads of State's trade unions', in Nyerere's phrase, and guaranteed the sanctity of colonial borders. Largely for this reason, Africa's independent states, unlike their regimes, enjoyed far greater stability than had their counterparts in Latin America or Asia. The price, possibly worth paying, was unresponsive regimes, xenophobia towards other African nationals, and the collapse of pan-African dreams.

In order to dominate society, newly independent regimes sought to destroy or incorporate potential concentrations of independent power. These might be great foreign companies like Union Miniere, nationalized in 1967. They might be regional or ethnic units, for, apart from the prolonged civil wars already described, many states had at least one region hankering for autonomy but incapable of asserting it against the power of modern weapons. Pre-colonial kingdoms could survive only if they coincided with modern states like Morocco or Swaziland; elsewhere they were early victims of centralizing regimes, as in Uganda in $1967 .{ }^{10}$

\section{MATERIALS AND DISCUSSION}

3.1 The Colonial Administration in Tanzania

The German introduced administration through districts which were helped by the local personnel including the akidas, liwali, jumbes, nyaparas, and headmen at the bottom. The German colony was divided into 22 districts of which two Iringa and Mahenge were still under the rule of the military personnel up to April 1, 1905 [11]. The district commissioner reported to the governor at the center Bagamoyo from 1885 to 1890 and later Dar es Salaam from 1890 to 1918 [12]. At the top of the hierarchy there was the governor who reported to the office of colonies in Germany. The functions of the administration were geared towards fulfilling the Germen needs specifically raw materials and the development of infrastructure [13].

The British situation was not different from that of the German system of administration except that they adopted indirect rule through the local institution of administration like the legal system, the tax system, the agricultural system, the police, the army, the

\footnotetext{
${ }^{10}$ John Iliffe, Africans the History of the Continent, Cambridge University Press, 2007

${ }^{11}$ German Annual Report 1908

${ }^{12}$ Osmund Kapinga, German Memories in the Matengo Highlands: the Cross Preceded the Flag, HAT Conference Paper 2018, Forthcoming

${ }^{13}$ German Annual Report 1908
} 
education system[ 14 ]. The British administrative structure was that of the governor at the top who was assisted by the secretariat of governors appointees, the LEGCO, the provincial administration under the Provincial Commissioner (PC), the functions of whom were to maintain peace and order in his area of jurisdiction, to administer legal justice, to recruit labour for public works and settler farmers, other duties as prescribed by the top authority. Appointment and the qualifications for the post included historians, sociologists, lawyers, administrators and anthropologists.

Under the PC there was a District Commissioner (DC) whose powers were limited to the district jurisdiction as set down by the powers incharge of the district administration. The prescribed jobs for the district commissioners included and not limited keeping of law and order, coerce labourers in public works and other colonial economic sectors which required cheap labour force and coordinate other colonial duties. To suppress the rebelling masses especially those organized around party politics. The district commissioners were also charged with the work of supervising local chiefs and receive feedback of activities conducted by local chiefs from their areas of their jurisdiction. All the posts at these levels were remunerated through the central administration. The features of the civil services were that of racial basis. Up to 1945 there was no African who reached the highest level of civil service ladder. The division between the senior and junior civil servants was that of between the European and non - European [15]. Through another commission the British authorities introduced a system of civil service based on competitive basis among candidates of all races, economic laws of inducements were invoked to justify salary scales for Europeans and non - Europeans and lastly non-Europeans appointed to such jobs were to receive three-fifths of the salary paid to Europeans of the same qualifications and doing the same job [16]. A second feature was that under the British colonial regime no government employee could join or participate in political associations- particularly T.A.N.U. In consequence, T.A.N.U. had to be organised and run by uneducated people, with the further result that, on the attainment of independence, the new

\footnotetext{
${ }^{14}$ Local Government Ordinance 1926

${ }^{15}$ Report of the [Lidbury] Commission on the Civil Services of the East African Territories and the East African High Commission (London, I954), vol. I, para. 21.

16 Anthony H. Rweyemamu, Managing Planned Development: Tanzania's Experience in The Journal of Modern African Studies, Vol. 4, No. 1 (May, 1966), p. 4
}

Government had to be run by politicians who themselves lacked education[17].

Below the district commissioners there were local chiefs who were commissioned to the control of the local population. The local chiefs operated through the Native Local Authority Ordinances and administrative lay out [ 18 ]. These were either traditional chiefs where they existed or appointees of the colonial authorities where they did not exist. Examples of local chiefs who were incorporated into the colonial government were Chaga chiefs, Merere of Usangu, etc.(authority) Appointed chiefs were Chief Burito Nyerere, Bambo Mkulungu of Wamatengo, Kahigi of Buhaya, etc.(authority) The main activities of the local chiefs were to collect tax, supervise public works, recruit labourers, etc. (authority) The local chiefs were assisted by village headmen who closely supervised all administrative activities at the grass root level.

The colonial administrative system was repressive and oppressive and segregative designed so as to fulfill their objectives of getting cheap raw materials, open up markets, acquisition of resources and collect taxes from the local people. The instruments of repression were put in place to coerce the local population to do what was required by the colonial state. The police force and the prisons were created to enforce the colonial laws [19].

\subsection{The Administrative System after Independence 3.2.1 Phase one administration Mwalimu Nyerere 1961 to 1985}

Julius Nyerere, the country's first President (1961 to 1985). As the rightful "Father of the Nation", he placed his impression on policy and development from very early on [20]. the Nyerere period led to a high degree of concentration of power at the centre. Economic, social and political power rested in the hands of a small political elite consisting more of party officials than government officers. Leadership was largely male but the few women, such Bibi Titi Mohamed, Lucy Lameck, Tabitha Siwale and Gertrude Mongella who held positions of power, were quite influential and respected. Public power was privatised in the sense of ending up in the hands of officials belonging to CCM - as a political party and a private organisation. The result was no public transparency or public accountability until his exit in 1985 .

17 Tanganyika Parliamentary Debates: National Assembly, Official Report (Dar es Salaam), Ist Session, 10 December 1962 to I6 February 1963, cols. I-10.

${ }^{18}$ Native Local Authority Ordinances

${ }^{19}$ Police force Ordinance

${ }^{20}$ Göran Hydén and Max Mmuya, Power and Policy Slippage in Tanzania-Discussing National Ownership of Development Sidastudies no. 21,2008 pg. 31 
The constitutional conference took place in March, 1961 in the capital, Dar es Salaam Karimjee Hall. According to its decisions on 01 May 1961 Tanganyika has received a full autonomy (Legislative Council has been renamed into National Assembly, and Council of Ministers - in the Cabinet). Declaration of independence of Tanganyika took place on 09 Dec 1961. Apart from the TANU there were several other political movements: African National Congress (ANC), National Convention Party (NCP), National Initiative Party (NIP) and others. Within one year, on 09 Dec 1962, the country has been proclaimed a republic. The one-party system TANU was established only in March, 1963. In 1965, mainland Tanzania adopted an interim constitution that declared it as a oneparty state led by the Tanzania African National Union (TANU).

Tanzania adopted the Independence Constitution which was based on the West Minister model except that it had no bill of rights. It provided for a Governor General representing the Queen as the Head of State; an executive prime minister from the majority party in parliament; a cabinet of ministers collectively and individually responsible to parliament and an independent judiciary [21]. This was based on the Her/His Majesty as the head of the state and the Governor General the Prime Minister as the head of the government [22]. Mwalimu Nyerere was the first Prime Minister who was assisted by his first cabinet of the following team; Minister without Portfolio Rashidi Mfaume Kawawa, Education Minister Oscar Kambona, Commerce and Industry Asanterabi Nsilo Swai, Local Government Minister Job Lusinde, Minister of Communications, Electrical Power and Construction Amir Jamal, Minister of Lands, Forests and Wildlife Tewa Saidi Tewa, Minister of Justice Chief Abdalah Said Fundikira, Health Minister Dereck NM Bryceson, Agriculture and Cooperatives Minister Paul Bomani, Finance Minister Sir Ernest Vassey and Interior Minister Clement G. Kahama [23].

At the regional level the administrative structure retained the colonial system whereby the country was divided into ten provinces administered by Provisional Commissioners and 58 districts under District Commissioners whose duties were to administer law and order at the respective level [24].

\footnotetext{
${ }^{21}$ Tanganyika Independence constitution 1961

22 The Independence Constitution 1961

${ }^{23}$ Paul Bjerk, (2015), Building a Peaceful Nation Julius Nyerere and the Establishment of Sovereignty in Tanzania, 1960-1964, University of Rochester Press

pg.76 Colin Leys, Tanganyika: The Realities of Independence, International Journal, Vol. 17, No. 3 1962,pg. 258
}

Local government was operating at the local level through the Native Authority Ordinance of 1926[25].

Soon after Nyerere's resignation from his position of Prime Minister in favour of Rashid Mfaume Kawawa in January $22^{\text {nd }}$ to $9^{\text {th }}$ December 1962 , the post of Provincial Commissioner was abolished and politically appointed "Regional Commissioners" were placed in charge of the restyled provinces. One of their chief tasks was to co-ordinate "village and district plans" which were to be drawn up by development committees at every level. These plans would indicate the precise tasks to be accomplished [26].

\subsubsection{Republican Constitution 1962}

A new constitution was due and much depends on it. A presidential republic was certain. It has also been announced that reserved seats for minorities will be abolished, and universal suffrage introduced, at the next election. This almost certainly means the end of all minority representation. The key remaining issue was really whether the Presidency, which $\mathrm{Mr}$. Nyerere seems bound to occupy, will be an executive one, as in the United States, or a formal one with a Prime Minister, as in India: or a combination of some kind, as in France. Mr. Nyerere has stated his conviction that the distinction between reigning and ruling is foreign to Africa and hence he favours an executive Presidency. If this principle is adopted, and Mr. Nyerere becomes such a President, his resignation as Prime Minister will have been of purely tactical value and several of the longstanding problems which his independent position as President of TANU offers him an opportunity of solving will recur. On the other hand, it will be difficult in the extreme to fill an executive Presidency with any other leader [27].

The November 1962 elections were a success for Nyerere. He won 98 percent of the vote, with Mtemvu polling only twenty thousand votes nationwide. The elections punctuated the drive to independence with a final formal separation from the Queen of England and removal of the British governorgeneral. Tanganyika became a republic under Nyerere's presidency.

With independence, all these things pertaining to the civil service had to be changed. In the Three-Year Development Plan (I961-64), the nationalist Government specifically allocated money for a crash pro-gramme for training indigenous civil servants. The pressure upon the new ministers for Africanisation and 'localisation' was both political and practical. The political drive for Africanisation came from trade union

\footnotetext{
URL: https://www.jstor.org/stable/40198635

${ }^{25}$ The Native Authority Ordinance, 1926

${ }^{26}$ Leys, op.cit. 266

${ }^{27}$ Leys, Ibid 268
} 
organisations and the African members of the civil service who for decades had been subjugated and subordinated; the practical need for localisation was due to the fact that with independence there was likely to be an exodus of expatriates who were not prepared to serve under an indigenous government.

\section{Civil Service}

By the end of December I96I, of the total 4,452 senior and middle-grade posts in the civil service, 1,170 were filled by Africans. Three years later, the total number of officers serving in senior and middlegrade posts on permanent terms had increased to 5,389. Of these, 3,083 or 57 per cent were local citizens [28]. This was as far as any well-meaning government could go. For Africanisation without drastically lowering standards of performance could only go as far as there were men and women possessed of a minimum education. No matter how much in-service training is given, it is only in very rare, exceptional circumstances, that a man who has had only primary schooling can possibly rise to the senior scale of the civil service hierarchy.

The problem was vividly summed up by the Africanisation Commission of 1962. Pointing out that there were only 200 Africans entering Form I of the secondary schools in I962, the Commission added: 'it will take at least five years before these 200 emerge as University graduates or qualified professionals'[29]. On the other hand, a survey of high-level manpower needs revealed that between 1962 and 1967 the additional administrative and professional manpower needed for growth and replacement was at least 5,600[30].

Throughout 1962 and the first half of 1963, Tanganyika underwent administrative changes on a scale never before witnessed. The first innovation was to replace the former civil-service Provincial and District Commissioners with political appointees. All Provinces were restyled 'Regions' and all Districts, 'Areas', under Regional Commissioners and Area Commissioners respectively [31]. Beginning early in 1963, the local government system also underwent changes. With the abolition of traditional chieftainship, the former colonial-inspired local authorities were transformed into elected councils for rural areas and

${ }^{28}$ Establishment Circular No. E.B. 8/0o 13 of 26 January I 965.

${ }^{29}$ Report of the Africanisation Commission, i962 (Dar es Salaam, 1963), p. 2.

${ }^{30}$ George Tobias, High Level Manpower Requirements and Resources in Tanganyika, 1962-I967 (Dar es Salaam, I963).

${ }^{31}$ Regional and Regional Commissioners Act, No. 2 of 962, and Area Commissioners Act, No. I8 of I962. It seems that the terms 'Area' and 'District' continue to be used inter- changeably. town councils in the urban areas [32]. The District Council Chairman is normally the T.A.N.U. District Chairman, while the Secretary is also the Area Commissioner for the Administrative District. The Executive Officer, who is appointed by and is responsible to the Local Government Service Commission, does most of the administrative work for the District Council. The District was further subdivided into divisions and villages, each under Divisional, Assistant Divisional, and Village Executive Officers, respectively. Sub-district officers were appointed by the District Council, but since January 1965 they, too, come under the Local Government Service Commission. Their duties include the maintenance of law and order, the collection of local rates, and the stimulation of local development effort [33].

Structural changes and innovations were here considered from the point of view of administrative efficiency and their fitness for tackling the problems of nation-building with the maximum speed but without disrupting society. Under the British colonial system, the Governor, as head of the administration, maintained a clear line of command, by way of the Chief Secretary in the Secretariat, down to the Provincial and District Commissioners. These links provided a solid hierarchy of the establishment, performing the same services and sharing a common loyalty. This solidarity was so strong that in the field Provincial Commissioners were in fact identified by the masses as 'the Administration'. It was therefore imperative that, following independence, changes should be made in the structure to ensure loyalty and solidarity to a new government. The politicisation of the civil service commissioners and the subsequent opening of T.A.N.U. membership to all government employees took place in response to this need.

The British colonial civil service was particularly renowned for efficiency and dedication to duty-albeit, duty as defined by the Colonial Office. It comprised men and women who, while priding themselves for being apolitical, nevertheless possessed

\footnotetext{
${ }^{32}$ The Chiefs were abolished by the African Chiefs Ordinance (Repeal) Act, No. 13 of 1963.

${ }^{33}$ Ministry of Local Government and Housing, 'Local Government in Tanganyika' (mimeo, Dar es Salaam, I965); Ministry of Local Government and Administration, Circular to all Regional Commissioners of Io July 1962. For a good analysis of recent changes, see William Tordoff, 'Regional Administration in Tanzania', in The Journal of Modern African Studies (Cambridge), iii, , May I965, pp. 63-89. The Court system was also reorganised to comprise a three-tier system of High Court, District Courts, and Primary Courts-all under a unified and independent judicial system.
} 
sound academic training. Those who managed to secure promotion to the level of, say, Provincial Commissioner or District Commissioner were men who had spent many years in public service and had therefore proved that they were capable of assuming major responsibilities. But, as a result of the failure to promote Africans, by the time of independence there were very few local people who had in fact benefited from the British administrative skills and experience.

\subsubsection{Politicization of civil service}

Thus, the politicisation of the regional and local administration was not and could not be matched by complete Africanisation, or indeed localisation, of the civil service. When, for example, the Regional Commissioner took over, the former expatriate Provincial Commissioner, if he decided to stay, became the Administrative Secretary in the new Regional Administration. At the same time those few Africans who had obtained higher education and/or administrative skills during the colonial era were moved to the capital as Assistant Permanent Secretaries, on their way to the top posts vacated by retiring British expatriates.

Absence also allowed the passage of strong legislation against the labor movement and opposition. ${ }^{34}$ Over the course of 1962, the Tanganyikan government passed laws and instituted practices that helped to construct a bureaucratic authority that was independent of Nyerere's prodigious personal authority. The government began working out the details of the new republican constitution. Envisioned "strong executive powers and necessary control of the legislature," Less than a month later, a different set of African Regional Commissioners were appointed for the whole country. The government had been preparing more stringent labor legislation. the formation of a commission on Africanization. In March

Kawawa beheaded the labor movement by offering the moderate Kamaliza the Ministry of Health and Labour and sending the radical Tumbo off as the high commissioner to London, He did the same with TANU firebrand Nsilo Swai, giving him a position in Tanganyika's UN office in New York

The central administration of the country must be kept, or perhaps made, capable of sustaining the large strains involved in effective development. From this point of view a sudden rapid loss of expatriates is serious, because in the short run there are no qualified substitutes. Various expedients are being tried. Ten junior ministers have been appointed - in effect, this involves a strengthening of African participation in the senior Civil Service. The structure of the Civil Service has been altered to allow higher promotion for middle-

${ }^{34}$ Paul Bjerk, op. cit. pg. 78 grade officers with talent [35]. In a long-run solution must be found to the current anarchy of labour relations. The trade union movement in 1960 covered nearly a quarter of the total labour force of Tanganyika. The total labour force, however, is less than half a million. The largest union had 25,000 members; the third largest, 10,000. The result combined power with financial or organizational weakness. Coupled with the attractions which militancy offers to ambitious political leaders, this combination has led to a steady decline in industrial relations. While the losses from strikes are by no means vast they, too, are more serious considered in relation to the delicacy of the economy, serious in some vital industries of Tanzania's elites ${ }^{36}$, President Nyerere administration by making the regional and district tees and renaming the positions, respectively. Each of these political appointees was to be assisted by regional administrative secretary and area secretary, ensure TANU (Tanganyika African National Union) supremacy at the regional and district levels, and to the government bureaucracy at regional and district participation there " $\left[{ }^{37}\right]$. In order bureaucracy at the regional and district level, the post of TANU party secretary, assisted by aide, who was a full-time official employed by the 1967 Arusha declaration, which nationalized Tanzania, set the nation along the path toward declaration and the later 1971 TANU party reforms as attempts to ensure party control and popular support. Yet the reality of administrative relationships between political elites and civil servants was not cordial.

\subsubsection{Local Government}

One major goal of the post-independence government was to have in place a system of administration which was democratic, but which also consolidated nationhood. The Local Government set up had to be revisited. As a measure of consolidating independence and nationhood, the Local Government Ordinance was amended in 1962 to, inter alia, repeal the Native Authority Ordinance and with it, native authorities and chiefs. In 1963, the African Chiefs Ordinance (Repeal) Act abolished the institution of the chieftaincy, and later in the same year, the Chiefs (Abolition of Office: Consequential Provisions) Act made it illegal for former chiefs to seek judicial redress for loss of office. All the associations identified by ethnicity were banned and debates regarding ethnic interests were prohibited in the parliament. The Native Authority system was abolished and the local government authority was absorbed into the new government [38]. The government simply planned to rationalize local governance with elected village and

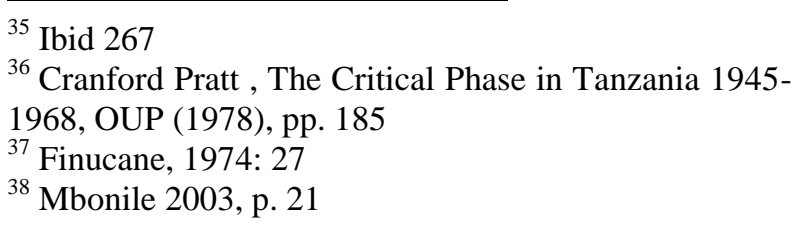


district councils and appointed executive officers under the new TANU-appointed area commissioners. But the policy was still under development. The minister of local government, issued a more far-reaching paper, titled "Position of Chiefs," announcing that, beginning January 1, 1963, chiefs and chiefdoms would no longer be elements of local governmental authority or organization.

As local leaders in the former colonial direct rule were replaced by directly elected party members, ethnicity-based authorities were destroyed [39]. Most of these chiefs were absorbed into the government as administrators [40 ]. In the end, local (particularly district) Authorities collapsed. District Authorities were abolished on 30 June 1972 while urban Authorities were abolished on June 30 1973. At the time of their abolition, there were 66 district councils and 15 urban councils in Tanzania. The period between 1972-1982 is generally known as the "Decentralization Period". Here, the Government experimented with taking power to the people by decentralising Central Government. A system of deconcentration of the government system replaced the comprehensive Local Government system which had existed for a decade. The new system was aimed at giving the people decision making powers on matters affecting their welfare and of local importance and to give them the personnel and finances for their implementation. Regions and districts were to plan and implement local development activities as well as administer their own local affairs with very limited interference from the seat of Central Government, Dar es Salaam. "Participation" became a catchword and a rallying slogan. Development councils were created in the districts and in urban areas. The aims of this Decentralization Programme were that:- Rural development should be managed at district and regional levels;

- Rural development should be co-ordinated centrally;

- The people should be involved in the development process;

- Rural development should be effectively planned and controlled Thus Local and Central Government responsibilities were merged. This was meant to result into a strong Central Government organization for coordinating and supervising rural development, which it was believed, would increase people's control of the development process in their own areas[41].

\footnotetext{
${ }^{39}$ Eun Kyung Kim, Nationalism and Its Impact on Democratization in Tanzania OMNES : The Journal of Multicultural Society, 2018 pg.76

${ }^{40}$ URT PORLGA, History of Local Government ${ }^{41}$ ibid
}

Mwalimu Nyerere had warned against this danger. That the transfer of power to the regions and districts must not also mean a transfer of a rigid and bureaucratic system from Dar es Salaam to lower levels. Nor is it the intention of these proposals to create new local tyrants in the person of the Regional and District Development Directors. Of late these worries of Mwalimu Nyerere became true hence reinstatement of local authorities. There was a ten-year break, as in 1972 the Local Government was abolished and replaced with a direct central government rule. The reintroduction of the Local Government occurred in the beginning of the 1980s, when the rural councils and rural authorities were reestablished.

\subsubsection{Reinstatement of Local Authorities}

When Local Authorities were abolished, urban councils were merged with neighbouring rural areas. Government focus was on rural areas and this led to a rapid deterioration of conditions in urban areas. Primary schools lacked textbooks and their buildings remained unmaintained; drains and sewers remained unblocked, roads went unattended, and dispensaries lacked essential drugs.

An outbreak of cholera in many urban areas in 1976 prompted the Government to set up an investigation team and to make recommendations on the future administration of urban areas. The report that was submitted recommended the reinstatement of urban Local Governments.

The Urban Councils (Interim Provisions) Act of 1978 required the re-establishment of town and municipal councils effective from 1July 1978. However, reconstituting these Local Authorities was not an easy task. The experienced manpower that Local Authorities had previously created had dispersed, and much of the infrastructure that belonged to Local Authorities had deteriorated, much beyond repair.

In 1980, the ruling political party, Chama cha Mapinduzi (CCM), required the Government to revive the Local Government system in its entirety. In 1982, legislation was enacted establishing village councils, township authorities and district councils as the Local Authorities in rural areas; and town, municipal and city councils as Local Authorities in urban areas. Local Government elections took place in 1983 and Local Governments were reinstated effective from 1984.

Socialism was the ideology that held it together especially during the 1970s. There was policy slippage, not the least in building ujamaa villages and promoting rural development, but it was less due to corruption, nepotism or such similar informal factors than to the lack of a functioning and reliable "system". Because Nyerere wanted "to run while others walk", any question asked about what was being attempted by 
the ruling party was regarded as "treason". Most leaders in the party hierarchy remained silent; those who raised questions were removed (Hyden 2006b). This power structure, however, began to collapse in the early $1980 \mathrm{~s}$ as, out of frustration, people decided to take matters into their own hands.

\subsubsection{Second Phase Administration -The Mwinyi period 1985-1995 (Awamu ya Ruksa)}

It fell upon the second President, Ali Hassan Mwinyi, to carry out the necessary economic reforms that Nyerere had refused to allow or had not wished to be associated with. His government was now in a weak bargaining position and he had to strike an agreement with the International Monetary Fund that forced a radical shift to market economics.

In the latter part of the 1980s, he and his party colleagues adopted the Zanzibar Declaration which allowed political leaders to accumulate personal wealth, an opportunity that they had been denied by the Arusha Declaration of twenty years earlier. Although there were a few exceptions, it is quite remarkable how little private wealth accumulation there had been in Tanzania until the 1980s when it began, initially illegally and after the Zanzibar Declaration, legally. The important consequence of the relatively strict discipline of the party leadership during the Nyerere days is that no indigenous middle-class with economic power really developed in Tanzania as it had, for instance, in neighbouring Kenya.

The President himself was not strong-willed as his predecessor had been and took the greatest pleasure in being able to approve requests for favours that came his way, hence his reputation among Tanzanians as President Ruksa.

The return to multi-party politics in 1992 was initially perceived as a challenge by $\mathrm{ccm}$, but once it realised that the opposition parties were led by groups of disgruntled and opportunistic individuals, many of whom had previously held leading positions in the ruling party, this fear soon abated. By the time the first multi-party election was held in 1995, CCM'S hegemony was confirmed although its candidate,

Perhaps the most significant aspect of the Mwinyi years, however, was the institutionalisation of a range of informal practices. Political clientelism intensified, especially with the arrival of competitive politics. The habit among ordinary people of seeking favours, rather than engaging in productive activities of their own, reinforced this informal institution. It also paved the way for corruption, which grew with the decrease in value of public sector wages and salaries that followed in the wake of the continuing devaluation of the local currency.
In short, by the end of the Mwinyi period, political stability relied more on informal personal networks than on functioning formal institutions, whether state or market. The attempt by a group of 55 $\mathrm{ccm}$ members of parliament to create a separate government for mainland Tanganyika in 1993 is an example of the political rivalries within ruling circles at the time. Tanzania remained a rather rudderless vessel and it fell upon Nyerere as Father of the Nation to make authoritative interventions to stabilize the situation.

\subsubsection{Towards Reforming Local Government}

The re-established Authorities continued to have a number of fundamental problems particularly limited resources and poor performance. By the late 1980 s there was general agreement within the Government and the ruling political party that Local Government needed reform. The fundamental problems faced by Local Authorities were categorised under six headings: - Institutional and legal framework - which regulates the relations between Central and Local Government was complex and was somewhat ambiguous and fragmented. overlaps and conflicts between major pieces of legislation, The Central Government continued to exercise excessive controls over Local Governments such as approving their revenue sources and budgets, and their by-laws. The limited capacity of councils did not prevent them from Centralising authority within themselves, compared to lower tiers of administrative set-up that is wards, mitaa, village governments, communities and user groups

- Governance - problems emanated from the fact that the relations between political leaders at national and local evel, civil society organisations and the Local Government Authorities were weak and sometimes antagonistic.

-Finances - Local Government Authorities operated under severe financial constraints. Underfunding was significant.

- Human resource capacity and management - most staff working in the Local Government Authorities were not accountable to them, but to the Local Government Service Commission and/or parent ministries.

- Capacity of Central Government institutions (URT, 1996) - there was limited capacity of the relevant Central authorities. Government institutions to design, develop and implement measures that would help promote a stronger Local Government system.

\subsubsection{Phase Three Administration - The Mkapa period 1995 - 2005 (Serikali ya Ukweli na Uwazi)}

If the Nyerere years were a blind race toward a false paradise and the Mwinyi period a chaotic free-forall dance in the rediscovered marketplace, the next ten years under the country's third President were an 
attempt at a more disciplined march toward specific policy goals ${ }^{42}$

Despite the significant changes that President Mkapa was responsible for introducing, much of the old legacies remain. They help explain the public complaints and slippage that continue to affect policy implementation. With no serious and credible competition from the political opposition, CCM enjoys the monopoly of power as a state party. Perhaps the most significant change in the Tanzanian power map during the Mkapa years was the extent to which the international community, through international finance institutions and donor agencies, managed to get a hold on Tanzania's destiny. Because the Tanzanian Government during Mkapa's time in power was anxious to restore international credibility, it found itself with few options other than to comply with these organizations in their role as agenda setters. This was reinforced toward the end of his presidency when the donor community began to consider direct budget support as a mechanism for improving their aid.

President Mkapa did not appreciate the importance of strong government institutions. To a greater degree than his predecessors he paid attention to strengthening the capacity of government institutions. $\mathrm{He}$ set in motion several large-scale reform programmes, not the least the one focusing on the public service. His outlook was more that of a "technocrat" than a "party populist". Unlike his predecessors who moved senior civil servants around at will President Mkapa, with only a few exceptions, retained them throughout his time as head of state in the positions to which they had been appointed. He promoted many women to senior positions in government and encouraged a reform that allowed greater female representation in parliament through election of women to special seats. His effort to reform government, however, was never deemed a success for two reasons. One was the universal standards against which it was assessed by development partners. The other was the lack of commitment on the part of those in charge of the reform prog]ramme in individual ministries. While the President had an excellent management team leading the effort from his office, it did not quite succeed in mobilising enough momentum within individual government ministries and executive agencies. It is fair to conclude that never before had the donors and the Government of Tanzania been closer in their adherence to a common set of policy objectives; however this was never fully appreciated by the development partners who failed to assess Tanzania on its own power terms. They were too ready to emphasise the great distance that Tanzania still had to go in order to be a global success rather than to show appreciation of the distance it had covered since the 1980s. They were too ready to focus on the abuse of official power rather than recognising the creative use of informal power to get things done.

\subsubsection{Reforming Local Government (1996-2005)}

The main principles of the Reform were pointed out in the Government's policy paper on Local Government Reform published in October 1998. So, the overarching goal of the reform is "to create good governance based on political and financial accountability, democratic procedures, and public participation". These are: The Financial Dimension, The Administrative Dimension, The Central-Local Relations, The Service Function Dimension, The Democratic Dimension,

\subsubsection{Achievements in Local Government Reform since 1996}

One of the major achievements in effecting Local Government Reform has been the changes in the legal and institutional framework affecting Regional and Local Administration as follows: Restructuring Regional Administration, Amendment of Local Government Laws, Strengthening of democracy at grassroots level, Codes of Conduct Regulations for staff and Councilors have been prepared and enacted with the objective of ensuring good governance at local level, In the end it is hoped that there will be in the country a strong, efficient, effective and democratic system of Local Government in Tanzania.

\subsubsection{Phase Four Administration - Kikwete period 2005-2015 (Ari Mpya, Kasi Mpya Nguvu Mpya)}

Jakaya Kikwete was elected as Tanzania's fourth President in late 2005. His slogan of ari mpya, kasi mруа ngиvи труа was so inspirational, coupled with his impromptu visits to the government service providing institutions, instilled to the population new hope in govenance. However, individual enrichment among political leaders was becoming not only increasingly evident but also more and more openly criticized. Although Tanzanians find engaging in collective action to be difficult - most efforts failing to get off the ground or fizzling out quite early - the poorer segments of the population are becoming increasingly agitated especially since much of the enrichment has been associated with scams involving the misuse of public funds. ${ }^{43}$ In the minds of many, Tanzania has become a country of mafisadi, these are individuals who engage in acts of corruption. The print media have also become an important player in prying open official matters that were previously hard to probe. The good example was the Richmond scandal in electric power generation scam which forced the Prime

${ }^{42}$ Hyden and Mmuya, op. cit. pg 36

${ }^{43}$ Hyden and Mmuya, op. cit.pg 38 
Minister to step down in 2008 as a signal for accountability. ${ }^{44}$

There is growing frustration among many Tanzanians, especially in the urban areas, that the government is not doing enough to punish those involved in these scams. To be sure, President Kikwete has acted to remove some ministers, including his former Prime Minister, but none of them have been prosecuted. Instead, they have been allowed to return to their home constituencies where the local party bosses have organized events welcoming them back as heroes. Because they are "local sons" and have brought tangible benefits to their districts, people there do not see that they have done anything wrong. While they appear corrupt to those who have not benefited from their actions, their local constituents view them as successful patrons.

Clientelism remains entrenched in Tanzania as it does in so many other African countries $\left[{ }^{45}\right]$. The rule of law and adherence to formal institutions is still trumped quite often there as elsewhere. It is obvious that corruption scandals are regarded as increasingly costly to the party but it prefers to deal with these issues internally rather than through the courts. At the meeting of its National Executive Committee on June 15, 2008 it was agreed that those involved in corruption scandals would be held responsible for their actions according to the Party's constitution.

The number of women in parliament was again increased as a result of the 2005 election. Approximately one third of all members are now female and there is a promise of an increase to $50 \%$ at the next election. This rapid increase and the promise of an even greater number of women have been possible in Tanzania because women can be elected on a special slate. Only a small number of these women have actually won a regular constituency seat. This increase in women legislators means that new perspectives are being brought to bear on several issues. Some of these women are quite outspoken and a few have challenged government on such sensitive issues as corruption. Yet, none of them has yet shown the clout that some of the previous women leaders had due to the fact that they had been forced to compete with strong men in order to win their respect and power, a matter that was acknowledged by the Tanzanian Women's Parliamentary Group at its meeting in Dodoma on April 26,2008 . The increased presence of women seems to have broadened the debate on key social and economic issues, but it remains to be seen what difference it really

\footnotetext{
44 Parliamentary Richmond Report (H.Mwakyembe Report 2008)

45 Michael Bratton and Nicholas van de Walle, Democratic Experiments in Africa Regime Transition in Comparative perspective, 1997.
}

makes to the issue of who wields power in Tanzania. This new situation also has implications for development partners. They are no longer as dominant as they used to be although the country's level of aid dependence remains high - approximately $42 \%$ of the annual budget in 2007. They continue to insist on the global reform agenda and try to push Tanzania in the directions of "good governance" and "poverty reduction". With increased direct budget support, it is not clear whether they are effective in achieving this objective since their levers are weaker than in the days when individual project and programme aid prevailed. It is clear, however, that with direct budget support and a role greater in policy formulation than policy implementation, it is necessary to enhance expertise on how politics works in the country.

The state institutions during the Fourth Phase administration, were reorganized to be in line with the existing governance challenges. The actions taken by the current administration, particularly in public service reform, and the functioning of public oversight institutions, anti-corruption, and the role of the state in economic development; should represent a significant shift in the country's political economy. Given the historically close relationship between the CCM and the Tanzanian state, particular attention will be paid to party management, and the party's changing position vis-à-vis the state. Agood example was when an attempt to change constitution was blocked by the ruling party CCM in 2014. Consequently, the Kikwete administration called on exit in 2015 the government and administrative systems were not strong enough to manage the national issues. ${ }^{46}$ That explains why the fifth phase government had to come with very hard approach in the dealing issues of national interest. ${ }^{47}$ These tough measures through the popular slogan of hapa kazi tu prompted the government to be accused of condoning dictatorial tendencies. Regulatory and government agencies were revitalized by introducing stringent control mechanisms and assigning office bearers who would be more responsive and accountable from a single central point where appointments and terminations were made.

\section{CONCLUSION}

The post colonial administration was in the first place a continuation of the colonial civil service and the local government system. The Independence constitution was typical of Westminster model with clear separation of powers between the pillars of the state namely executive, the legislature and the judiciary. Checks and balances were entrenched into the

46 John Mnyika the opposition parliamentarian vehemently castigated the fourth phase government for being inept in dealing with national issues

${ }^{47}$ John Magufuli, Presidential speech inaugurating the National Assembly in Dodoma, Novemba 2015, 
constitution of Tanganyika. However, the 1962 republican constitution staged what we can call as a constitution coup $\mathrm{d}$ tat by removing all the west model minster model structure of constitution and replace it with an imperial presidential system of administration. The president was to become part of the national assembly with powers to dissolve parliament at discretion and powers to assent bills before they became laws. This kind of constitution has continued until the present.

Furthermore, the civil service was first Africanized and extensively politicized with TANU cadres systematically replacing the civil service posts left by departing European expatriates who left after independence and the subsequent Africanization. At independence there were few educated Africans qualified to take over the running of administration. The party role in the administration was consolidated with the one-party constitution of 1965 . The party supremacy entrenched itself in the administration of Tanzania until the present time. The failure of constitutional change in 2014 was the result of the ruling party reluctance to allow more democratic participation in the affairs of the nation. The sitting president promised to further the process from where it had experienced a stalemate. But the process has not been revived to date. ${ }^{48}$ There had been changes in the administration in terms of personalities whose role has been at the center of each phase. More popular phases are ujamaa of Nyerere, ruksa of Mwinyi, ukweli na uwazi of Mkapa, kasi mpya, nguvu mpya na ari mpya of Kikwete and hapa kazi tu of Magufuli. This postcolonial administration has not to a great extent been able to spearhead development of the country despite abundance of resources. The cry is to change constitution so as to distance the administration from the influence of the ruling CCM monopoly.

Despite of efforts of the fifth phase government hapa kazi tu, to assume aggressive developmentalist stance, the government and administrative machinery have not substantially changed to disengage from the colonial legacy. The institutions, the structure and the perceptions of the office bearers have not been able to cater for persistent developmentalist call envisaged. There is very slight change between the early post-colonial state which inherited administrative machinery designed in the era of neocolonial context to that of the late postcolonial state.

\section{REFERENCE}

1. Bjerk, Paul, Building a Peaceful Nation Julius Nyerere and the Establishment of Sovereignty in Tanzania, 1960-1964, University of Rochester Press, (2015),

2. Eriksen, Stein Sundstøl Tanzania: A Political Economy Analysis, Norwegian Institute of International Affairs 2018

3. Haque, M Shamsul, "Context less nature of public administration in third world countries," International Review of Administrative Sciences, vol 62 (1996)

4. Hydén, Goran and Mmuya, Max, Power and Policy Slippage in Tanzania-Discussing National Ownership of Development Sidastudies no. 21,2008

5. Iliffe, John. Africans the History of the Continent, Cambridge University Press, 2007

6. Ko de Ridder Ben Emans Rudie Hulst Albertjan Tollenaar (editors), Public administration in Tanzania, African Public Administration and Management series, vol. 3 Studies Centre / University of Groningen / Mzumbe University 2015

7. Leys, Colin, Tanganyika: The Realities of Independence, International Journal, Vol. 17, No. 3 1962, pg. 258

8. Maina, Chris Peter, "Constitution-Making in Tanzania: the Role of the People in the Process"

9. Mamdani, M. Citizen and Subject: Contemporary Africa and the Legacy of Late Colonialism. Princeton: Princeton University Press. 1996.

10. Rweyemamu, Anthony H., Managing Planned Development: Tanzania's Experience in The Journal of Modern African Studies, Vol. 4, No.

11. Samoff, Joel, Popular Initiatives and Local Government in Tanzania: The Journal of Developing Areas, Vol. 24, No. 1 (Oct., 1989),

12. Saul, John, The State in Post-colonial Societies :Tanzania, 1974*

13. Schneider, Leander. "Colonial Legacies and Postcolonial Authoritarianism in Tanzania: Connects and Disconnects," African Studies Review, Vol. 49, No. 1 (Apr., 2006),

14. Tanzania Country Review, 2019, https://www.countrywatch.co

15. Tobias, George. High Level Manpower Requirements and Resoarces in Tanganyika, 1962I967 (Dar es Salaam, I963).

16. Tordoff, William "Regional Administration in Tanzania", in The Journal of Modern African Studies (Cambridge),

17. URL: https://www.jstor.org/stable/40198635

\footnotetext{
48 Hotuba ya Rais wa Jamhuri ya Muungano wa Tanzania, Mheshimiwa John Pombe Joseph Magufuli, akifungua rasmi Bunge jipya la Jamhuri ya Muungano wa Tanzania, Dodoma, 20 Novemba 2015
} 